\title{
SAFETY EVALUATION OF A HEAVY OIL-DEGRADING BACTERIUM, RHODOCOCCUS ERYTHROPOLIS C2.
}

\author{
Hisae AOSHIMA ${ }^{1}$, Tatsuaki HIRASE ${ }^{1}$, Takakiyo TADA ${ }^{1}$, Naoya ICHIMURA ${ }^{1}$, Hiroyuki KATO ${ }^{2}$, Yohei NAGATA ${ }^{2}$, \\ Takeshi MYOENZONO ${ }^{3}$, Mitsuru TAGUCHI ${ }^{3}$, Kazuo TAKAHASHI ${ }^{4}$, Takao HUKUZUMI ${ }^{4}$, Takuya AOKI ${ }^{5}$, \\ Seiichi MAKINO ${ }^{5}$, Kozo HAGIYA ${ }^{6}$ and Hiroyuki ISHIWATA ${ }^{6}$
}

\author{
${ }^{1}$ KRI Inc., Kyoto Research Park, 134 Chudoji-minami-machi, Shimogyo-ku, Kyoto 600-8813, Japan \\ ${ }^{2}$ Daiwa Can Company, 2-1-10, Nihonbashi, Chuo-ku, Tokyo 103-8240, Japan \\ ${ }^{3}$ Kanto Natural Gas Development Co. Ltd., 3-1-20 Nihonbashi Muromachi, Chuo-ku, Tokyo 103-0022, Japan \\ ${ }^{4}$ Maeda Corp., 2-10-26 Fujimi, Chiyoda-ku, Tokyo 102-8151, Japan \\ ${ }^{5}$ Nippon Koei Co. Ltd., 4-2 Kojimachi, Chiyoda-ku, Tokyo 102-0083, Japan \\ ${ }^{6}$ Nishimatsu Construction Co. Ltd., 1-20-10 Toranomon, Minato-ku, Tokyo 105-0001, Japan
}

(Received November 14, 2006; Accepted December 14, 2006)

\begin{abstract}
The safety of an oil-degrading bacterium, C2 strain, was evaluated for utilization in an open system for bioremediation of oil-contaminated environments. The $\mathrm{C} 2$ strain was identified as Rhodococcus erythropolis by performing an alignment analysis of the whole 16S rRNA sequence. $R$. erythropolis was classified as a nonpathogenic (category 1) bacterium. Biological and biochemical properties of the $\mathrm{C} 2$ strain also confirmed its nonpathogenicity. The pathogenicity and basic ecotoxicity were studied in laboratory animals and in a variety of test species, respectively. General and inhalation toxicities were not detected; additionally, there was no evidence of skin irritation, mutagenic potential, eye irritation, skin sensitization, ecotoxicity or notable pathogenicity. The comparison of these results with human exposure levels and previously published data indicates that the $\mathrm{C} 2$ strain appears to be safe for utilization in bioremediation of polluted environments, requires no special occupational health precautions during the application process, and has a low environmental impact. This study suggests that the $\mathrm{C} 2$ strain could be suitable for bioremediation of oil-contaminated environments.
\end{abstract}

KEY WORDS: Bioremediation, Safety Evaluation, Rhodococcus erythropolis

\section{INTRODUCTION}

Hydrocarbon contamination caused by oil tanker accidents, storage tank ruptures and transport accidents results in widespread environmental pollution. Furthermore, environmental pollution caused by hydrocarbons at old petrol stations or factory sites is also a serious problem, since it not only damages the environment but the sale value of the land also significantly decreases. Physical techniques such as combustion and solidification have been carried out to remove hydrocarbons from contaminated soils. Although physical techniques may shorten the work period with low costs, plants are unable to grow in these soils. Microbial degradation of chemical compounds such as hydrocarbons that cause environmental contamination is well known as a major pathway in the natural decontamination process (Leavy and Colwell, 1990; Prince, 1993). Therefore, various useful bacteria have been isolated and investigated for utilization in bioremediation of polluted environments (Margesin, 2000; Ward et al., 2003; Whyte et al., 1998). The Ministry of Economy, Trade and Industry (METI) and the Ministry of Environment established "Operating guidelines for bioremediation by microorganisms" on March 31, 2005, to develop and expand bioremediation technology. Since bacteria are used in open systems, it is necessary to evaluate the safety of these bacteria based on these guidelines prior to the application of bioremediation technology. Thus far, only five bacterial strains that degrade aromatic hydro-

Correspondence: Hisae AOSHIMA (E-mail: hisae.aoshima@vc60.com) 
carbons such as toluene, phenol, dioxin and trichloroethylene (TCE) have received the agreement confirmation for bioremediation technology (Okamura et al., 2002; Teramoto et al., 1999; Sugiura et al., 2003; Hirai et al., 2005). However, to date, no oil-degrading bacterium has been registered under the guidelines.

In our previous study, several oil-degrading bacteria were isolated from various places in Japan, and their degradation characteristics for some types of oil were assessed. Of more than 50 isolated bacteria, C2 strain was found to be the most effective in degrading several types of mineral oil. The $\mathrm{C} 2$ strain was able to degrade $60 \%$ of heavy oil with a concentration of more than $20 \mathrm{~g} / 1$ under aqueous conditions in only 3 days. Furthermore, the degradability of heavy oil improved to $85 \%$ by reducing its viscosity (Aoshima et al., 2006). In this study, we investigated the physiological and ecological characteristics of the $\mathrm{C} 2$ strain in order to determine its applicability to bioremediation technology. All animal experiments were performed within the guidelines for studies of laboratory animals.

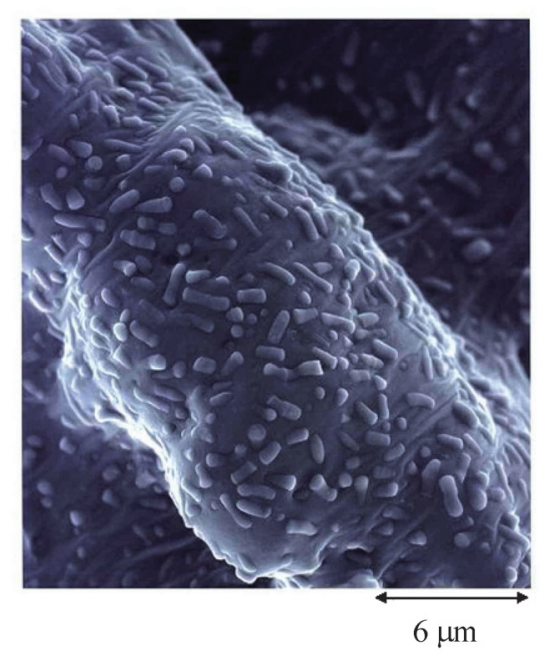

Photo 1. Electron micrograph of R. erythropolis $\mathrm{C} 2(\times 5.0 \mathrm{~K})$.

\section{MATERIALS AND METHODS}

\section{Bacterial strains and growth conditions}

The C2 strain was isolated from Nishinomiya, Hyogo prefecture, in our previous study (Photo. 1) (Aoshima et al., 2006). Rhodococcus erythropolis type strain (IFO 15567), R. equi type strain (IFO 14956) and Escherichia coli DH5 $\alpha$ (Toyobo, Osaka, Japan) were purchased. All strains were usually grown on a Luria broth (LB) medium at $30^{\circ} \mathrm{C}$ and maintained at $4{ }^{\circ} \mathrm{C}$.

\section{Denaturing gradient gel electrophoresis analysis of polymerase chain reaction products}

Chromosomal DNA of each bacterial strain was extracted according to the method described in the Fast DNA SPIN Kit. Both 16S rRNA and the spacer region of each bacterial strain were amplified using Taq DNA polymerase and the Mastercycler gradient. Polymerase chain reaction (PCR) amplification of $16 \mathrm{~S}$ rRNA and the spacer region were carried out using the primer pairs D1-F and D1-R, and SPF-clamp and SP-2R, respectively (Table 1). Amplification reactions were performed using $10 \mu \mathrm{mol} / \mathrm{l}$ of the constructed primers in a total volume of $50 \mu \mathrm{l}$ containing $15 \mathrm{mmol} / \mathrm{l}$ Tris$\mathrm{HCl}(\mathrm{pH} 8.0)$ and $50 \mathrm{mmol} / \mathrm{K} \mathrm{KCl}$ buffer, $1.5 \mathrm{mmol} / \mathrm{l}$ $\mathrm{MgCl}_{2}, 2.0 \mathrm{mmol} / \mathrm{l} \mathrm{dNTP}$ mixture, $2.5 \mathrm{U}$ KOD Plus (Toyobo), and $10 \mathrm{ng} / \mu \mathrm{l}$ template DNA. The PCR thermocycling program of $16 \mathrm{~S}$ rRNA was as follows: 1 cycle at $94^{\circ} \mathrm{C}$ for $5 \mathrm{~min} ; 32$ cycles at $94^{\circ} \mathrm{C}$ for $1 \mathrm{~min}$, $52^{\circ} \mathrm{C}$ for $1 \mathrm{~min}, 72^{\circ} \mathrm{C}$ for $1 \mathrm{~min}$ and $72^{\circ} \mathrm{C}$ for $3 \mathrm{~min}$. The PCR thermocycling program of the spacer region was as follows: 1 cycle at $94^{\circ} \mathrm{C}$ for $5 \mathrm{~min} ; 32$ cycles at $94^{\circ} \mathrm{C}$ for $1 \mathrm{~min}, 54^{\circ} \mathrm{C}$ for $1 \mathrm{~min}, 72^{\circ} \mathrm{C}$ for $1 \mathrm{~min}$ and $72^{\circ} \mathrm{C}$ for $3 \mathrm{~min}$.

The denaturing gradient gel electrophoresis (DGGE) analysis of the PCR products was performed using a $16 \times 16 \mathrm{~cm}$ and 1 -mm-thick $7.5 \%$ polyacrylamide gel (ratio of acrylamide to bisacrylamide, 37.5:1) containing a $40 \%$ to $70 \%$ gradient of urea and formamide. The electrophoresis was carried out at 70 volts

Table 1. Primer sequences for PCR amplification of 16S rRNA.

\begin{tabular}{ll}
\multicolumn{1}{c}{ Primer } & \multicolumn{1}{c}{ Sequence } \\
\hline D1-F & 5'-CCT ACG GGA GGC AGC AG-3' \\
D1-R & 5'-CCG TCA ATT CCT TTG AGT TT-3' \\
SP-2R & 5'-CAG ACA CCA ACA AAA ACC AC-3' \\
SPF-clamp & 5'-TGC GGC TGG ATC ACC TCC TTT C-3' \\
GC clump* & 5'-CGC CCG CCG CGC CCC GCG CCC GTC CCG CCG CCC CCG CCC G-3' \\
\hline
\end{tabular}

*GC clamp was connected to 5'-termial of D1-F and SPF-clamp. 
Safety evaluation of an oil-degrading bacterium.

and $58^{\circ} \mathrm{C}$ for $16 \mathrm{hr}$ using a PROTEAN II xi2-D cell (Bio-Rad Laboratories, CA, US). The gel was stained with 10,000-fold SYBER Gold (Funakoshi Inc., Tokyo, Japan) in TAE buffer for $30 \mathrm{~min}$. The stained gel was washed 3 times with TAE buffer, and the DNA band was observed by ultraviolet irradiation.

\section{Microbiological and biochemical characterizations}

The growth curve of bacteria was monitored by a biophotorecorder (Advantec MFS Inc., CA, US) at 60 rpm under various conditions.

The catalase (EC 1.11.1.6) activity of the bacterial strains was evaluated by adding hydrogen peroxide to the cultured sample. If the bacterial strain produces catalase, it will convert hydrogen peroxide into oxygen. The evolution of gas bubbles is indicative of a positive test. The quantitative analysis of the catalase activity was performed by the colorimetric assay (Catalase Assay Kit; Calbiochem-Novabiochem International, Inc., CA, US) (Fossati et al., 1980). The oxidase (EC 1.9.3.1) activity of each bacterial strain was examined according to the method of the Cytochrome $\mathrm{C}$ Oxidase Kit (CYTOC-OX1; Sigma-Aldrich, MO, US). Morphological features such as possession of a flagellum were observed under a microscope. The hemolysis property was determined by the presence or absence of lysis of goat erythrocytes. The lysis of erythrocytes was estimated by a visual test of the agar plate containing goat erythrocytes and each bacterial strain. The auxotrophy assay was performed according to the method of the ID test (Nissui Pharmaceutical Co. Ltd., Tokyo, Japan).

\section{Toxicity studies in rats}

An acute oral toxicity was carried out on rats according to OECD (Organisation for Economic Cooperation and Development) guideline (No. 401, 1981). For determining acute oral and inhalation toxicities and intravenous dosage in rats, the $\mathrm{C} 2$ strain (1.0E+08 CFU/body) was suspended in LB medium and administered once orally by gavage, transtracheal, and parenteral administration to groups of five male and five female animals after overnight fasting. The animals were observed daily for 21 days after dosing, and they were then killed and subjected to autopsy. For determining acute oral toxicity, a PCR/DGGE analysis was performed on the chromosomal DNA extracted from the stool samples of test animals. Routine clinical observations such as body weight and food consumption were carried out throughout the study period. Terminal hematology and clinical chemistry investiga- tions were performed, and on completion of the respective treatment periods, all animals were subjected to gross pathological examination and organ weight analysis.

\section{Irritation studies}

A primary skin irritation test was carried out on rabbits according to the method of the Code of Federal Regulations (Code of Federal Regulations, 1979), adapted to OECD Guidelines forTesting of Chemicals (No. 406, 1981). The backs of five male and five female animals were clipped free of hair, and 1.0E+08 $\mathrm{CFU} /$ rabbit of the test material was introduced under a gauze $(2.5 \times 2.5 \mathrm{~cm})$. The patches were secured for a 24-hr exposure period and covered with impervious materials. The patches and the residual test material were removed with water after $24 \mathrm{hr}$, and any skin reactions were evaluated at 0 to $48 \mathrm{hr}$ after removal.

An eye irritation test was carried out on rabbits in accordance with the OECD guidelines (No. 405, 1981), and the test results were evaluated according to the Code of Federal Regulations (1980). Three rabbits were used for the experiment, and an equivalent of 0.1 $\mathrm{ml}$ of test material containing $1.0 \mathrm{E}+07 \mathrm{CFU}$ of the $\mathrm{C} 2$ strain was instilled into the conjunctival sac of their left eye; the grade of ocular reaction was recorded at 0 to $48 \mathrm{hr}$ after instillation.

A modified Draize test was performed to test skin sensitization according to the method described by Johnson and Goodwin (1985). Skin sensitization was tested by induction and challenge procedures on a group of 20 guinea pigs. The test consisted of an induction phase, resting period, and subsequent challenge phase to demonstrate whether sensitization occurred in the guinea pigs. The induction procedure involved three intradermal injections of $0.1 \mathrm{ml}$ of test materials containing 1.0E+07 CFU of the C2 strain at sites overlying the axillary and inguinal lymph nodes in 20 animals. Ten animals were injected in a similar manner with $0.9 \%$ sterile saline (negative control). All animals were challenged epicutaneously 35 days later under the 6 -hr occluded patch test condition by using the test material. One week later, all animals were challenged intradermally in the flank with $0.1 \mathrm{ml}$ of test material. All animals were rechallenged epicutaneously 1 week later to confirm the result of the first epicutaneous challenge.

\section{Ecotoxicology}

To test the toxicity of the $\mathrm{C} 2$ strain in an aquatic environment, a 30-day semistatic test for acute toxicity 
in carps was carried out in accordance with the OECD guidelines (No. 203, 1984). Ten carps (Cyprinus carpio) weighing $5 \mathrm{~g}$ each were maintained in an aquarium containing $1.0 \mathrm{E}+06 \mathrm{CFU} / \mathrm{ml}$ of the $\mathrm{C} 2$ strain. The bacterial solution was renewed at 48 -hr intervals by using dechlorinated water containing $1.0 \mathrm{E}+06 \mathrm{CFU} / \mathrm{ml}$ of the $\mathrm{C} 2$ strain. The concentration of the $\mathrm{C} 2$ test sample was examined by plating on LB agar at 72-hr intervals during the study. The carps were monitored daily for signs of toxicity.

The toxicity for small zooplankton was tested by adding the $\mathrm{C} 2$ strain, and the ability to immobilize the water flea Daphnia magna was assessed over a 24-hr period under static conditions in accordance with the OECD guidelines (No. 211, 1998). Five D. magna individuals were placed in a test tube containing an aqueous solution of the $\mathrm{C} 2$ strain at $1.0 \mathrm{E}+06 \mathrm{CFU} / \mathrm{l}$. The aqueous solution containing the $\mathrm{C} 2$ strain was changed 3 times a week over an exposure period of 21 days. Routine observations such as swimming behavior, body height, death rate, age of the first egg, number of cumulative eggs, and monitoring of water temperature, $\mathrm{pH}$, oxygen demand, and total hardness were carried out throughout the study period. The number of C2 strain cells was counted by plating on LB agar.

The toxicity for algae was assessed by an algal growth inhibition test in accordance with the OECD guidelines (No. 201, 1981). We measured the inhibitory effect of the test material on the growth of the unicellular green alga Selenastrum capricornutum ATCC 22662. A culture of the alga (initial concentration: $1.0 \mathrm{E}+04$ cells $/ \mathrm{ml}$ ) was exposed to different concentrations of the $\mathrm{C} 2$ strain (initial concentrations: $1.0 \mathrm{E}+04$ CFU/1, 1.0E+05 CFU/1, and 1.0E+06 CFU/1). The culture was incubated on an orbital shaker under continuous illumination at $100 \mathrm{rpm}$ at $24^{\circ} \mathrm{C}$ for $72 \mathrm{hr}$. The growth was monitored daily by measuring the absorbance of each culture at $665 \mathrm{~nm}$. Routine observations such as swimming behavior, body height, death rate, age of the first egg, number of cumulative eggs, and monitoring of water temperature and $\mathrm{pH}$ were carried out throughout the study period. The number of C2 strain cells was counted by plating on LB agar.

\section{Mutagenicity}

Extracellular substances secreted by the C2 strain were examined for mutagenic activity using Salmonella typhimurium TA100 (Pedersen, 1988). Extracellular substances were prepared by centrifuging $(5,000$ $\mathrm{rpm}, 10 \mathrm{~min}, 4^{\circ} \mathrm{C}$ ) to remove $\mathrm{C} 2$ cells and concentrated using a freeze-dried process. A liquid culture assay was used. S. typhimurium TA100 was exposed to five doses of test material (from 0.1 to $10 \mathrm{mg} / \mathrm{ml}$ incubation mixture at half-log intervals) in a phosphate-buffered nutrient broth for $3 \mathrm{hr}$. After incubation, the test substance was removed by centrifugation before plating. The number of revertants to prototrophy and viable cells was estimated. The test was conducted in the presence and absence of a metabolic activator, namely a liver preparation from male rats pretreated with Aroclor 1254 and cofactors required for mixed-function oxidase activity (S-9 mix). The sensitivity of $S$. typhimurium TA100 was assessed by a notable increase in the number of revertant colonies induced under similar liquid conditions by diagnostic mutagens.

\section{RESULTS AND DISCUSSION}

Comparison and genealogical analysis of $16 \mathrm{~S}$ rRNA sequences from the $\mathrm{C} 2$ strain and other strains indicated that the sequence of the $\mathrm{C} 2$ strain was identical to that of $R$. erythropolis HXN2000 (100\%), CNCM2208 (99\%), CNCM2204 (99\%), DSM43066 (99\%), and IFO15567 (98.85\%) and Rhodococcus sp. 67-BEN001(100\%) and 871-AN053 (100\%)(in-depth data not shown). Therefore, C2 strain was identified as $R$. erythropolis. The pathogenicity of the bacteria that belonged to Rhodococcus was investigated based on information from the literature. Previous reports revealed that $R$. equi and $R$. facians are severely pathogenic for animals and plants, respectively (Cornelis et al., 2001; Ghanassia et al., 2002). R. equi causes foal pneumonia and human opportunistic infections, while $R$. facians causes crown gall of tobacco leaves. The database of pathogenic bacteria maintained by METI also listed $R$. equi as pathogenic to mammals. In other studies, $R$. sputi caused boar tuberculosis and lymphadenitis, $R$. aurantiacus caused cerebral meningitis in a cancer patient, and $R$. erythropolis was detected in AIDS patients (Prinze et al., 1985; Tsukamura et al., 1988; Vernazza et al., 1991). However, since the identification of these three bacteria was incomplete, it is doubtful whether these bacteria are pathogenic.

Some Rhodococcus species have been used in industrial processes. For example, $R$. rhodochrous produces citric acid and steroids, and Rhodococcus sp. converts benzonitrile to benzoic acid and produces glutamic acid. $R$. erythropolis is also used in acrylamide production and as a bacterial flocculant. These industrial applications suggest that most of the Rhodococcus species, including $R$. erythropolis, are safe.

The basic characteristics of the $\mathrm{C} 2$ strain were 
Safety evaluation of an oil-degrading bacterium.

compared with those of $R$. equi. The PCR/DGGE profiles of $16 \mathrm{~S}$ rRNA showed that the electrophoretic pattern of the $\mathrm{C} 2$ strain was similar to that of $R$. erythropolis IFO 15567 (Photo. 2). However, the electrophoretic pattern of the $\mathrm{C} 2$ strain was different from that of $R$. equi IFO 14956. The primer pair SPF-clamp and SP-2R, which was designed from the specific spacer (sp) regions of the $\mathrm{C} 2$ strain, could amplify chromosomal DNA from the $\mathrm{C} 2$ strain and $R$. erythropolis IFO

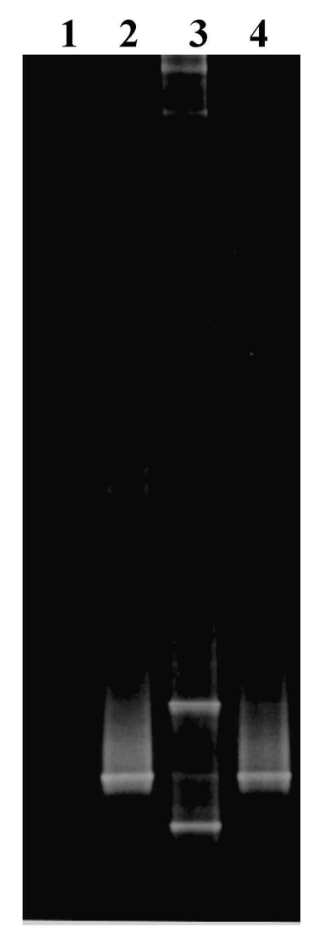

Photo 2. PCR/DGGE (40\% to $70 \%$ denaturing gradient gel) profiles of $16 \mathrm{~S}$ rRNA using the primer pair D1-F and D1-R. Lanes: 1, negative control; 2, R. erythropolis IFO 15567; 3, R. equi IFO 14956; 4, C2 strain.
15567. In contrast, the chromosomal DNA from $R$. equi IFO 14956 was not amplified. This result indicated that the DNA sequence of the $\mathrm{C} 2$ strain was completely different from that of $R$. equi. The monitoring method for determining the number of only $\mathrm{C} 2$ strain cells was developed by PCR/DGGE analysis using this specific primer pair for the $\mathrm{C} 2$ strain present in soil and water environments (unpublished data). Using this method, the number of $\mathrm{C} 2$ strain cells was detected to be more than $1.0 \mathrm{E}+04 \mathrm{CFU} / \mathrm{g}$ or $\mathrm{CFU} / \mathrm{ml}$.

The optimum growth condition of the $\mathrm{C} 2$ strain was $30^{\circ} \mathrm{C}$ and $\mathrm{pH} 7.5$ in LB medium. The $\mathrm{C} 2$ strain was also able to grow in the $\mathrm{pH}$ range from 5.0 to 9.0. The growth of the $\mathrm{C} 2$ strain occurred in the presence of $7.5 \% \mathrm{NaCl}$. Furthermore, the $\mathrm{C} 2$ strain could grow in only $0.5 \%$ yeast extract as well as in LB medium (data not shown). The biochemical properties such as gram stain, acid fastness, catalase activity, oxidase activity, hemolysis, fermentative ability, and motility of the three bacterial strains were completely identical (Table 2). However, the biochemical characteristics of the $\mathrm{C} 2$ strain and $R$. equi differed with regard to the utilization of various carbon sources (Table 3 ). The growth curves of the C2 strain, R. erythropolis IFO 15567, and R. equi IFO 14956 were monitored at $40^{\circ} \mathrm{C}$. R. equi IFO 14956 but not the $\mathrm{C} 2$ strain and $R$. erythropolis IFO 15567 grew at $40^{\circ} \mathrm{C}$ (Fig. 1). Furthermore, parasitism, symbiotic performance, zygosity and sporulation by $R$. erythropolis have not been reported.

\section{Toxicity study}

In the acute oral toxicity and inhalation assessments, the rats showed no clinical signs, and all the rats were found to survive during the treatment period and in the 21-day observation period. No treatment-related clinical signs were observed in either study with intravenous dosage. Body weight gain and food and water consumption were not affected by the treatment. Hematology and clinical chemistry investigations did

Table 2. Phenotypic characteristics of C2 strain, R. erythropolis IFO 15567, and R. equi IFO 14956.

\begin{tabular}{|c|c|c|c|c|}
\hline Property & C2 strain & R. erythropolis IFO 15567 & R. equi & IFO 14956 \\
\hline Gram stain & + & + & & + \\
\hline Acid fastness & + & + & & + \\
\hline Oxidase & - & - & & - \\
\hline Catalase & + & + & & + \\
\hline Hemolysis & - & - & & - \\
\hline Fermentative ability & - & - & & - \\
\hline Motility & - & - & & - \\
\hline
\end{tabular}


H. AOSHIMA et al.

not reveal any changes in the values. Organ weight analysis showed no indication of adverse responses to the treatment. Consequently, the toxicity and inhalation median lethal concentration $\left(\mathrm{LD}_{50}\right)$ was demonstrated to exceed $4.0 \mathrm{E}+08 \mathrm{CFU} /$ body.

In the acute oral toxicity test, stool samples were collected and analyzed by PCR/DGGE using the primer pair SPF-clamp and SP-2R. The specific DNA band from the $\mathrm{sp}$ region of the $\mathrm{C} 2$ strain was detected in administered rats after only 1 day of administration. The number of $\mathrm{C} 2$ strain cells was estimated to be $1.0 \mathrm{E}+06$ to $1.0 \mathrm{E}+07 \mathrm{CFU} / \mathrm{g}$ based on the fluorescence intensity of PCR/DGGE profiles (data not shown). Thus, the C2 strain was immediately excreted from the rat's body, without an increase in its population. In acute inhalation, crepitation was identified in all experimental animals soon after administration. However, crepitation disappeared after a few hours, and there

Table 3. Biochemical properties of C2 strain, R. erythropolis IFO 15567, and R. equi IFO 14956.

\begin{tabular}{|c|c|c|c|c|}
\hline Item & C2 strain & R. erythropolis IFO 15567 & R. equi & IFO 14956 \\
\hline Hydrogen sulfide & - & - & & - \\
\hline Esculin & \pm & \pm & & - \\
\hline Phenylalanine & - & - & & - \\
\hline Indole & - & - & & - \\
\hline Voges Proskauer & - & - & & - \\
\hline Citric sodium & + & + & & \pm \\
\hline Lysine decarboxylase & \pm & \pm & & - \\
\hline Arginine dehydrolase & \pm & \pm & & - \\
\hline Ornithine decarboxylase & - & - & & - \\
\hline Ortho-nitrophenyl- $\beta$-D-galactopyranoside & \pm & \pm & & - \\
\hline Urease & + & + & & + \\
\hline Malonic acid & \pm & \pm & & - \\
\hline Adonite & - & - & & - \\
\hline Inositol & - & - & & - \\
\hline Raffinose & - & - & & - \\
\hline Rhamnose & - & - & & - \\
\hline Sorbitol & + & + & & - \\
\hline Sucrose & - & - & & - \\
\hline Mannite & + & + & & - \\
\hline L-arabinose & \pm & \pm & & + \\
\hline
\end{tabular}

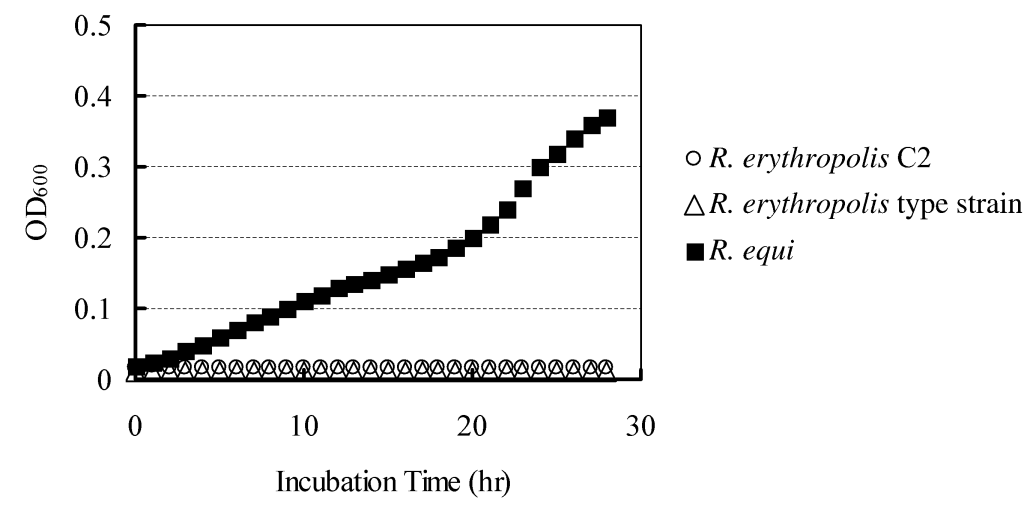

Fig. 1. Growth curve of the C2 strain, R. erythropolis IFO 15567, and R. equi IFO 14956 in LB medium at $40^{\circ} \mathrm{C}$. 
Safety evaluation of an oil-degrading bacterium.

was no significant difference between the negative control and the $\mathrm{C} 2$ test animals. This result suggested that crepitation was a nonspecific phenomenon caused by liquid invasion of the respiratory organs.

In the eye and skin irritation studies, the test material produced no corneal or iris reactions such as erythema, edema, or reddening at any time during the treatment period; furthermore, none of the animals showed skin irritation. Hence, the C2 strain was regarded to have a negative potential to cause eye injury and skin irritation. None of the test phases revealed any significant difference between the test and negative control animals.

Ecotoxicity examination of the carp showed no mortality or any other effects after 30 days of exposure. With regard to the aquatic organism toxicity for small zooplankton, the swimming behavior, body height, death rate, age of the first egg, and number of cumulative eggs were not notably affected by treatment with the $\mathrm{C} 2$ strain (data not shown). However, the number of the $\mathrm{C} 2$ strain cells remained at approximately $50 \%$ of the initial concentration during the experimental period. The number of cumulative eggs in the negative control was slightly higher than that in the $\mathrm{C} 2$ test (Fig. $2)$. However, this result showed no significant demographic differences ( $t$ test, $\alpha=0.05$ ). With regard to the ecotoxicity for algae, the growth of the algal culture containing 1.0E+06 CFU/ml of $\mathrm{C} 2$ strain was inhibited after $48 \mathrm{hr}$ of exposure (Fig. 3). On the other hand, the number of $\mathrm{C} 2$ strain cells rapidly increased from 16- to 97-fold of the initial number at the end of the exposure period (Table 4). It was possible that the nutrient availability became restricted due to an increase in the number of $\mathrm{C} 2$ strain cells. The subsequent addition of nutrient sources enabled better growth of algal cells (data not shown). The decrease in the growth rate of alga might not directly depend on the $\mathrm{C} 2$ strain but may depend on nutrient insufficiency.

\section{Mutagenicity}

The C2 strain secretes extracellular substances such as fatty acid esters. Therefore, we performed gene mutagenicity tests to investigate the extracellular substances produced by the C2 strain (data not shown). There was no dose-related increase in revertants to prototrophy in any of the gene mutagenicity tests. All results were confirmed in an independent experiment, and it was concluded that there were no indications of mutagenic activity in the presence or absence of the C2 strain. Taken together, the results of the present study suggest that the $\mathrm{C} 2$ strain could be regarded as a nontoxic, nonpathogenic and nonmutagenic bacterium. Therefore, we concluded that $\mathrm{C} 2$ strain can be considered safe.

This study is the first to report on the safety evaluation of an oil-degrading bacterium for using bioaugmentation in industrial applications. The C2 strain has an exceptionally high possibility of adaptation to various polluted environments due to the following characteristics: (i) since the $\mathrm{C} 2$ strain can grow in the pres-

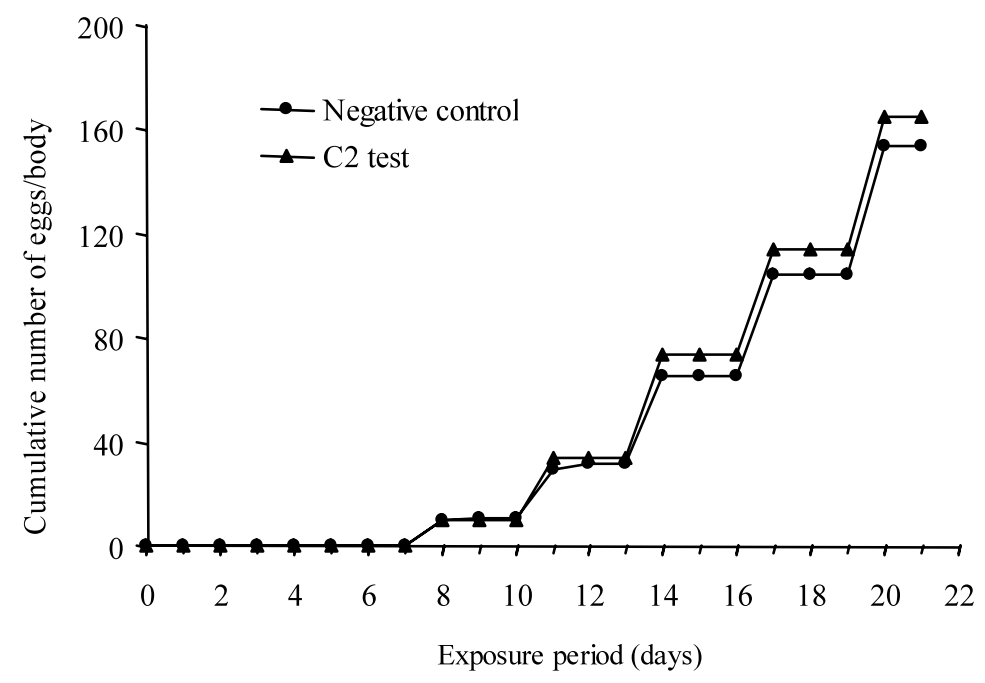

Fig. 2. Effect of the $\mathrm{C} 2$ strain on the number of cumulative eggs. Negative control (•) and C2 test ( $\bullet$ ). 


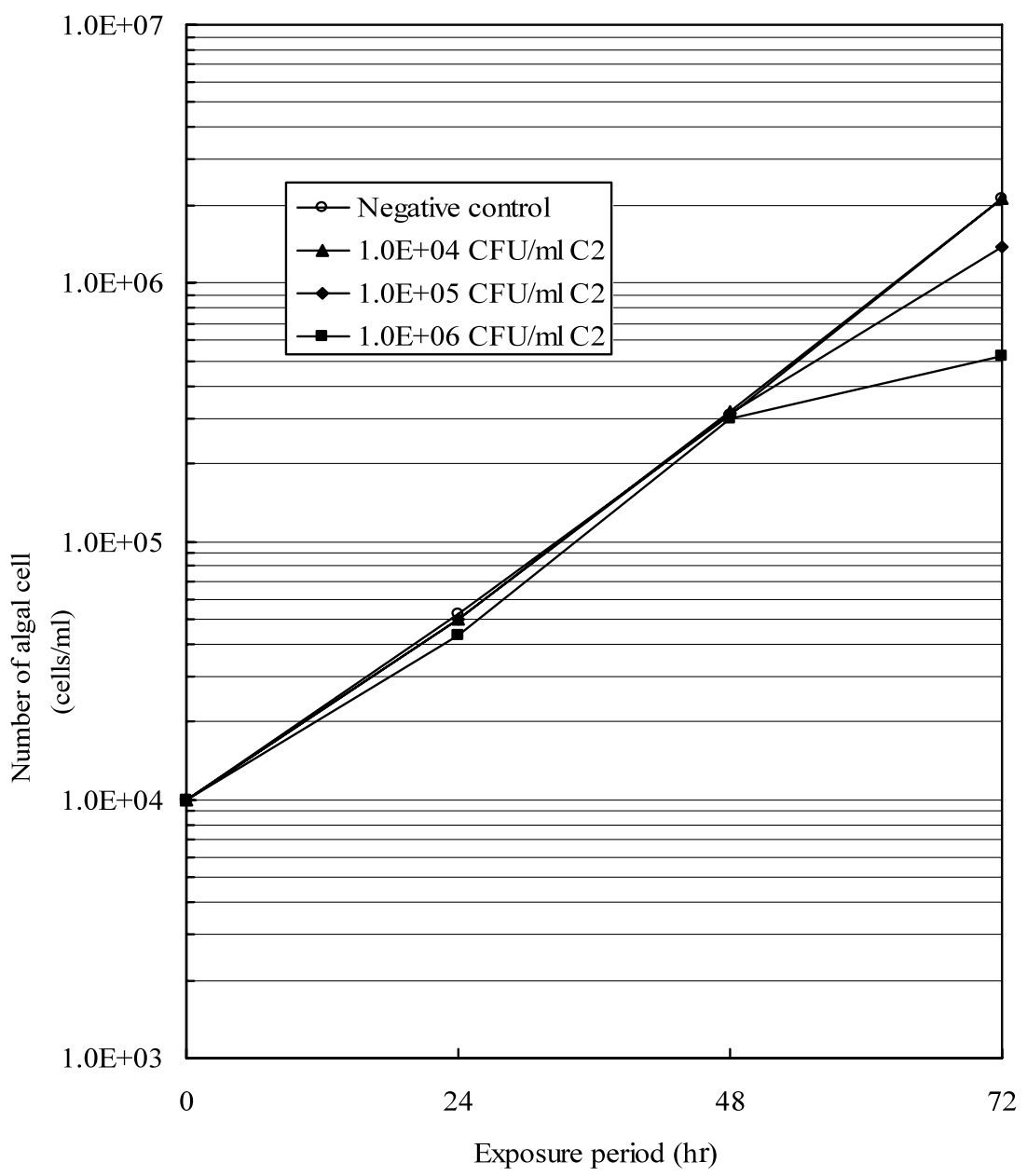

Fig. 3. Effect of the $\mathrm{C} 2$ strain on the number of algal cells. Negative control (o), $1.0 \mathrm{E}+04 \mathrm{CFU} / \mathrm{ml}$ of the $\mathrm{C} 2$ strain $(\Delta), 1.0 \mathrm{E}+05 \mathrm{CFU} / \mathrm{ml}$ of the $\mathrm{C} 2$ strain $(\bullet)$, and $1.0 \mathrm{E}+06 \mathrm{CFU} / \mathrm{ml}$ of the $\mathrm{C} 2 \operatorname{strain}(\boldsymbol{\bullet})$.

Table 4. Aquatic organism toxicity of $\mathrm{C} 2$ strain for algae.

\begin{tabular}{|c|c|c|c|c|}
\hline \multirow{2}{*}{ Item } & \multirow{2}{*}{ Negative control } & \multicolumn{3}{|c|}{$\mathrm{C} 2$ test } \\
\hline & & $1.0 \mathrm{E}+04 \mathrm{CFU} / \mathrm{ml}$ & $1.0 \mathrm{E}+05 \mathrm{CFU} / \mathrm{ml}$ & $1.0 \mathrm{E}+06 \mathrm{CFU} / \mathrm{ml}$ \\
\hline $\mathrm{C} 2$ (CFU/ml, initial) & Not detected & $5.07 \mathrm{E}+03$ & $2.93 \mathrm{E}+04$ & $3.97 \mathrm{E}+05$ \\
\hline $\mathrm{C} 2$ (CFU/ml, end) & Not detected & $4.90 \mathrm{E}+05$ & $1.12 \mathrm{E}+06$ & $6.30 \mathrm{E}+06$ \\
\hline growth magnification & 211 & 211 & 137 & 52 \\
\hline Inhibition rate $(\%)$ [0-72 $\mathrm{hr}$ area rule] & 0.0 & -0.5 & 26.5 & 58.4 \\
\hline Inhibition rate $(\%)$ [24-48 hr agogics] & 0.0 & -4.7 & -3.7 & -8.8 \\
\hline Inhibition rate $(\%)$ [24-72 $\mathrm{hr}$ agogics] & 0.0 & -1.4 & 10.1 & 33.2 \\
\hline $\mathrm{pH}$ & $7.7 \sim 7.8$ & $7.6 \sim 7.8$ & $7.5 \sim 7.8$ & $7.5 \sim 7.8$ \\
\hline Illuminance (lux) & \multicolumn{4}{|c|}{$4100 \sim 4600$} \\
\hline Number of revolutions (rpm/min) & \multicolumn{4}{|c|}{100.0} \\
\hline Water temperature $\left({ }^{\circ} \mathrm{C}\right)$ & \multicolumn{4}{|c|}{$22.9 \sim 23.0$} \\
\hline
\end{tabular}


Safety evaluation of an oil-degrading bacterium.

ence of $7.5 \% \mathrm{NaCl}$, it can be used for the bioaugmentation of contaminated seawater and coastal water; (ii) since the $\mathrm{C} 2$ strain demonstrated stable growth at $\mathrm{pH}$ 49 , it can adjust to various $\mathrm{pH}$ conditions; (iii) since the C2 strain is able to grow and degrade oil even at low temperatures $\left(10^{\circ} \mathrm{C}\right)$, it can adjust to various temperature conditions; and (iv) the C2 strain demonstrated stable growth even in a culture medium containing only a $0.1 \%$ yeast extract solution; thus, the cost of decontamination can be reduced. At present, a construction method needs to be developed that suits an individual oil-polluted area and maximizes the capabilities of the $\mathrm{C} 2$ strain. In the future, the confirmation of conformance of the $\mathrm{C} 2$ strain to the established guidelines and the practical utilization of this strain in bioremediation of oil pollution are expected.

\section{REFERENCES}

Aoshima, H., Hirase, T., Tada, T., Ichimura, N., Yamaguchi, H., Taguchi, M. and Myoenzono, T. (2006): Improvement of heavy oil degradation by Rhodococcus erythropolis C2. J. Environ. Biotechnol., 5, 107-109.

Code of Federal Regulations (1979): Title 16, Commercial Practices. No. 1500.41. Published by the Office of Federal Regulations. National Archives and Record Service, Washington DC.

Code of Federal Regulations (1980): Title 16, Commercial Practices. No. 1500.42. Published by the Office of Federal Regulations. National Archives and Record Service, Washington DC.

Cornelis, K., Ritsema, T., Nijsse, J., Holsters, M., Goethals, K. and Jaziri, M. (2001): The plant pathogen Rhodococcus fascians colonizes the exterior and interior of the aerial parts of plants. Mol. Plant. Microbe. Interact., 14, 599-608.

Fossati, P., Prencipe, L. and Berti, G. (1980): Use of 3, 5-dichloro-2-hydroxybenzenesulfonic acid/4aminophenazone chromogenic system in direct enzymic assay of uric acid in serum and urine. Clin. Chem., 26, 227-231.

Ghanassia, J. P., Gasser, B., Fraisse, P., De Briel, D. and Phillippe, E. (2002): Rhodococcus equi infection causing pulmonary malacoplakia in a patient with acquired immune deficiency syndrome. Ann. Pathol., 12, 174-177.

Hirai, H., Sugiura, M., Kawai, S. and Nishida, T. (2005): Characteristics of novel lignin peroxidase produced by white-rot fungus Phanerochaete sordida YK-624. FEMS Microbiol. Lett.,
246, 19-24.

Johnson, A.W. and Goodwin, B.F.J. (1985): The Draize Test and modifications. In Current Problems in Dermatology. 14, pp.13-48, Karger, Basel.

Leavy, J.G. and Colwell, R.R. (1990): Microbial degradation of hydrocarbons in the environment. Microbiol. Rev., 54, 305-315.

Margesin, R. (2000): Potential of cold-adapted microorganisms for bioremediation of oil-polluted Alpine soils. Int. Biodeterior. Biodegrad., 46, 310.

OECD guideline for acute oral toxicity (1981): Updated Guideline No. 401, adopted 1987.

OECD guideline for alga, growth inhibition test (1981): Updated Guideline No. 201, adopted 1984.

OECD guideline for Daphnia magna reproduction test (1998): Updated Guideline No. 211, adopted 1998.

OECD guideline for eye irritation (1981): Updated Guideline No. 405, adopted 1987.

OECD guideline for fish, acute toxicity test (1984): Updated Guideline No. 203, adopted 1992.

OECD guideline for skin sensitisation (1981): Updated Guideline No. 406, adopted 1992.

Okamura, K., Shibuya, K., Nakamura, K., Sasaki, M., Hasegawa, T. and Kawai, T. (2002): Verification test of bio-augmentation against TCE contamination. Technical News of Geo-Environmental Protection Center, 4, 19-24 (in Japanese).

Pedersen, P.B. (1988): SP 400 (batch no. LAJR 009+012): Testing of mutagenic activity with Salmonella typhimurium TA1535, TA1537, TA98, TA100, and Escherichia coli WP2uvrA (pKM101) in a liquid culture assay. Novo report no. 5388. Novo Nordisk A/S Bagsvaerd, Denmark.

Prince, R.C. (1993): Petroleum spill bioremediation in marine environments. Microbiol. Rev., 19, 217 242.

Prinze, G., Ban, E., Fekete, S. and Szabo, Z. (1985): Meningitis caused by Gordona aurantiaca (Rhodococcus aurantiacus). J. Clin. Microbiol., 22, 472-474.

Sugiura, M., Hirai, H. and Nishida, T. (2003): Purification and characterization of a novel lignin peroxidase from white-rot fungus Phanerochaete sordida YK-624. FEMS Microbiol. Lett., 224, 285-290.

Teramoto, M., Futamata, H., Harayama, S. and 
Watanabe, K. (1999): Characterization of highaffinity phenol hydroxylase from Comamonas testosteroni $\mathrm{R} 5$ by gene cloning and its expression in Pseudomonas aeruginosa PAO1c. Mol. Gen. Genet., 262, 552-558.

Tsukamura, M., Komatsuzaki, C., Sakai, R., Kaneda, K. and Seino, A. (1988): Mesenteric lymphadenitis of swine caused by Rhodococcus sputi. J. Clin. Microbiol., 26, 155-157.

Vernazza, P.L., Bodmer, T. and Galeazzi, R.L. (1991): Rhodococcus erythropolis infection in HIV- associated immunodeficiency. Schweiz. Med. Wochenschr., 121, 1095-1098.

Ward, O., Singh, A. and Van, H. J. (2003): Accelerated biodegradation of petroleum hydrocarbon waste. J. Ind. Microbiol. Biotechnol., 30, 260270.

Whyte, L.G., Hawari, J., Zhou, E., Bourbonniere, L., Inniss, W.E. and Greer, C.W. (1998): Biodegradation of variable-chain-length alkanes at low temperatures by a psychotrophic Rhodococcus sp. Appl. Environ. Microbiol., 64, 2578-2584. 